\title{
Hakikat Ganti Rugi Dalam Perspektif Hukum Ekonomi Syariah dan Hukum Perdata Indonesia
}

\author{
Hengki Firmanda* \\ Mahasiswa Program Doktor Ilmu Filsafat Universitas Gadjah Mada
}

\begin{abstract}
Abstrak
Tujuan penelitian untuk menjelaskan hakikat ganti rugi (dhaman) berdasarkan perspektif hukum ekonomi syariah dan hukum perdata Indonesia. Metode penelitian yang digunakan hukum normatif (legal research) dengan menfokuskan perbandingan hukum. Hasil penelitian ini dapat dijelaskan Indonesia menganut dual system dalam hal penerapan hukum ekonomi, yaitu hukum ekonomi syariah dan hukum perdata Indonesia. Implikasi dari dual system tersebut berpengaruh kepada seluruh aspek bisnis termasuk dalam konsep ganti rugi. Dhaman (ganti rugi) merupakan pemenuhan kewajiban berupa ganti kerugian oleh pihak yang merugikan atas hak dari pihak yang dirugikan baik berupa kerugian material maupun immaterial yang timbul pada saat pra-kontraktual, kontraktual dan pasca kontraktual. Dalam penelitian ini dapat disimpulkan bahwa hakikat ganti rugi menurut hukum perdata Indonesia mengacu kepada KUH Perdata di mana setiap penggantian kerugian baik itu material maupun immaterial selalu dijumlahkan dengan sejumlah uang. Hakikat ganti rugi dalam konsep hukum ekonomi syariah tidak menyebutkan dengan apa mesti diganti, boleh saja dengan uang atau bisa saja dengan jasa dan bahkan dianjurkan untuk memberi maaf kepada pihak yang merugikan tersebut.
\end{abstract}

\section{Kata Kunci: Ganti Rugi, Hukum Ekonomi Syariah, Hukum Perdata Indonesia}

\begin{abstract}
The purpose of the study is to explain the nature of compensation (dhaman) based on the perspective of sharia economic law and Indonesian civil law. The research method used normative law (legal research) by focusing comparative law. The results of this study can be explained Indonesia adheres to dual systems in the application of economic laws, namely sharia economic law and civil law of Indonesia. The implications of these dual systems affect all aspects of the business including the concept of compensation. Dhaman (compensation) is the fulfillment of obligations in the form of compensation by the adverse party on the rights of the injured party either in the form of material or immaterial losses arising in the pre-contractual, contractual and post-contractual. In this study it can be concluded that the nature of compensation according to Indonesian civil law refers to the Civil Code in which any compensation either material or immaterial is always summed with a sum of money. The nature of compensation in the concept of sharia economic law does not mention what should be replaced, it is okay with money or it could be with the service and even recommended to apologize to the adverse party.
\end{abstract}

Keywords: Indemnification, Sharia Economic Law, Indonesian Civil Law

"Penulis Korespondensi

E-mail: hengki.firmanda@gmail.com 


\section{Pendahuluan}

Ganti rugi dalam Kamus Besar Bahasa Indonesia menyepadankan dengan kompensasi yang artinya pemberesan piutang dengan memberikan barang-barang yang seharga dengan utangnya, ${ }^{1}$ sedangkan dalam Oxford Dictionary of Law kata kompensasi disebut dengan compensation. Compensation is monetary payment to compensate for loss or damage. When someone has committed a criminal offence that caused personal injury, loss, or damage, and he has been convicted of this offence or it was taken into account when sentencing for another, the court may make a compensation order requiring the offender to pay compensation to the person suffering the loss (with interest, if need be). ${ }^{2}$

Ensiklopedi Ekonomi dan Perbankan Syariah menuliskan ganti rugi (dhaman) ialah menjamin (menanggung) untuk membayar utang, mengadakan barang, atau menghadirkan orang pada tempat yang telah ditentukan. ${ }^{3}$ Dhaman dapat diterapkan dalam berbagai bidang muamalah, menyangkut jaminan atas harta benda dan jiwa manusia. Imam Mawardi mengatakan bahwa dhaman terdapat dalam pendayagunaan harta benda; tanggungan dalam masalah diyat; jaminan terhadap kekayaan; jaminan terhadap jiwa; dan jaminan terhadap beberapa perserikatan yang sudah menjadi kebiasaan masyarakat.

Untuk mengakomodasi pengertian tersebut dari telaah makna secara bahasa dan istilah dhaman (ganti rugi) di atas maka dapat penulis simpulkan makna dhaman (ganti rugi) berdasarkan perspektif hukum ekonomi syariah dan hukum perdata ialah pemenuhan kewajiban berupa ganti kerugian oleh pihak yang merugikan atas hak dari pihak yang dirugikan baik berupa kerugian material maupun immaterial yang timbul pada saat prakontraktual, kontraktual dan pasca kontraktual. Terkait pengertian yang penulis utarakan tersebut, dapat dijelaskan beberapa unsurunsur didalamnya, yaitu

1. Para pihak yaitu pihak yang dirugikan dan pihak yang merugikan.

2. Adanya kerugian berupa kerugian material dan kerugian immaterial, baik yang timbul pada pra-kontraktual, kontraktual, dan pasca-kontraktual.

3. Adanya pemenuhan kewajiban atas hak yang telah dirugikan.

Ganti rugi dalam ajaran Islam sudah diatur sedemikian sempurna. Hal ini karena Islam sebagai agama rahmatan lil 'alamin yang secara implisit maupun eksplisit sangatlah memperhatikan kemaslahatan setiap manusia. Wujud konkrit secara mendasar, Islam dalam terapan hukum-hukumnya selalu tidak jauh dalam ranah melindungi agama, jiwa, keturunan, akal, dan harta benda. Hal ini tidak hanya dalam ranah akidah dan ibadah saja, melainkan juga dalam hubungan ekonomi antara manusia satu dengan manusia lainnya (disebut muamalah).

Secara moral dan hukum, Islam sangat menganjurkan berperilaku jujur, amanah, dan adil dalam bermuamalah. Konsep keberperilakuan ini harus didukung dengan perbuatan dalam berpraktik ketika bermuamalah, seperti melarang memakan harta orang lain secara batil, melakukan penipuan dalam berbisnis, dan

${ }^{1}$ Kamus Bahasa Besar Bahasa Indonesia, (Jakarta: Pusat Bahasa, 2008), hlm. 795.

${ }^{2}$ Elizabeth A. Martin, A Dictionary of Law,(New York: Oxford University Press. Tanpa Tahun), hlm. 98-99.

${ }^{3}$ Habib Nazir dan Muhammad Hasanuddin, Ensiklopedi Ekonomi dan Perbankan Syariah, (Bandung: Kafa Publishing, 2008), hlm. 144. 
sampai kepada berperilaku seimbang atau adil dalam penggantian kerugian.

Esensinya agama Islam mengatur semua tentang pertanggungjawaban, baik itu yang diakibatkan oleh transaksi langsung maupun akibat pihak ketiga. Hal ini dapat dijumpai pada masa Nabi yang meletakkan pilar asas umum yang bertujuan untuk menghilangkan darar, yang dikenal dengan kaidah laa darara walaa diroro, yaitu setiap orang tidak boleh merugikan diri sendiri maupun merugikan orang lain.

Sebagai wujud aplikasi konsep pertanggungjawaban atau ganti rugi tersebut juga diterapkan di Indonesia.Penerapan hukum terkait pengaturan ekonomi di Indonesia dikenal dual system, yaitu menurut hukum konvensional yang berakar dari hukum Belanda dan menurut hukum Islam. Implikasi dual system inipun berpengaruh dalam penerapan teori ganti rugi berdasarkan konsep hukum perdata (Burgelijk Wetboek) dan berdasarkan hukum ekonomi syariah.

Dari penelusuran penulis, hakikat ganti rugi berdasarkan prespektif hukum ekonomi syariah dan hukum perdata belum pernah diteliti sebelumnya. Meskipun meneliti isu ganti rugi, tetapi tidak menyentuh masalah yang sama. Kristin Olivia Sumaa meneliti ganti rugi menurut Pasal 95 dan Pasal 96 Kitab Undang-Undang Hukum Acara Pidana (KUHAP) dalam proses pelaksanaannya terhadap error in persona. $^{4}$ Penelitian Yowanda P. Lumentut meneliti tentang tanggung jawab pelaku usaha memberikan ganti rugi atas kerusakan barang yang merugikan konsumen. ${ }^{5}$ Kuspraningrum Emilda meneliti tentang perbandingan ganti rugi pada gugatan wanprestasi dan gugatan perbuatan melawan hukum. ${ }^{6}$ Wesman Endom dan Subarudi meneliti tentang metode pendekatan penilaian ganti rugi lahan hutan. ${ }^{7}$ Hery Zarkasih meneliti tentang "pelaksanaan prinsip keadilan dalam pemberian ganti rugi pengadaan tanah untuk kepentingan umum (studi kasus pelebaran jalan raya di Kota Praya Kabupaten Lombok Tengah).

Penulis menemukan penelitian yang sedikit ada kemiripan dengan penelitian ini. Penelitian tersebut dilakukan oleh Asmuni pada tahun 2007 yang menjelaskan kaedah fiqh tentang ganti rugi secara hukum Islam. ${ }^{8}$ Perbedaan penelitian Asmuni dengan penelitian ini, yaitu Asmuni hanya menjelaskan ganti secara hukum Islam, sementara penelitian ini menjelaskan ganti rugi berdasarkan konsep hukum perdata (Burgelijk Wetboek/BW) dan ganti rugi berdasarkan konsep hukum ekonomi syariah.

Dengan demikian, bila ditelaah penelitian terdahulu itu maka sama sekali tidak menyentuh hakikat ganti rugi berdasarkan prespektif hukum ekonomi syariah dan hukum perdata. Dengan demikian, penelitian yang penulis lakukan merupakan kebaruan (novelty) sehingga dapat memberikan konstribusi bagi ilmu pengetahuan.

${ }^{4}$ Kristin Olivia Sumaa, Ganti Rugi Menurut Pasal 95 dan Pasal 96 KUHAP Dalam Proses Pelaksanaannya Terhadap Error in Persona, JurnalLex Crimen, Volume I, Nomor 3, Juli-September 2012, hlm. 57.

${ }^{5}$ Yowanda P. Lumentut, Tanggung Jawab Pelaku Usaha Memberikan Ganti Rugi Atas Kerusakan Barang yang Merugikan Konsumen, JurnalLex Privatum, Volume I, Nomor 3, Juli 2013, hlm. 5.

${ }^{6}$ Kuspraningrum Emilda,Perbandingan Ganti Rugi pada Gugatan Wanprestasi dan Gugatan Perbuatan Melawan Hukum, Jurnal Risalah Hukum, Volume 3, Nomor 1, Juni 2007, hlm. 25.

${ }^{7}$ Wesman Endom dan Subarudi, Metode Pendekatan Penilaian Ganti Rugi Lahan Hutan,Jurnal Analisis Kebijakan Kehutanan, Volume 8, Nomor 1, April 2011, hlm. 1.

${ }^{8}$ Asmuni, Teori Ganti Rugi (Dhaman) Perspektif Hukum Islam,Jurnal Millah, Volume VI, Nomor 2, Februari 2007. 
Adapun permasalahan dalam penelitian ini berangkat pertanyaan dari bagaimana hakikat ganti rugi (dhaman) berdasarkan perspektif hukum ekonomi syariah dan hukum perdata Indonesia? Untuk menjawab pertanyaan tersebut, penulis mengunakan pendekatan hukum normatif dengan pendekatan perbandingan hukum. Tujuan yang diharapkan dari penelitian ini untuk menjelaskan hakikat ganti rugi (dhaman) berdasarkan perspektif hukum ekonomi syariah dan hukum perdata Indonesia.

\section{Metode Penelitian}

\section{Pendekatan penelitian}

Pendekatan penelitian ini adalah perbandingan hukum. Pendekatan perbandingan hukum berguna untuk menyandingkan kedua jenis hukum yang berbeda, yaitu antara hukum ekonomi syariah dengan hukum perdata Indonesia.

\section{Sifat penelitian}

Penelitian ini bersifat penelitian deskriptif, yaitu penelitian yang ditujukan untuk menjelaskan dan menerangkan sesuatu, agar menjadi terang dan jelas. Penelitian ini menjelaskan perbandingan antara ganti rugi dalam hukum ekonomi syariah dengan hukum perdata. Semula ganti rugi dijelaskan menurut ekonomi syariah, kemudian dilanjutkan dengan gagasan yang ada di dalam hukum perdata Indonesia. Setelah diperbandingkan kemudian di dalam keduanya ditemukan sisi-sisi positifnya yang dimungkinkan dapat digunakan sebagai usulan dalam hukum perdata baru di Indonesia.

\section{Jenis data}

Jenis data yang digunakan data sekunder terdiri dari bahan hukum primer, bahan hukum sekunder, dan bahan hukum tersier. Bahan hukum primer diperoleh dari peraturanperaturan yang terkait dengan ganti rugi baik ekonomi syariah maupun perdata Indonesia. Bahan hukum sekunder diperoleh dari bukubuku tentang ganti rugi (dhaman) baik dalam perspektif ekonomi syariah maupun hukum perdata Indonesia. Bahan hukum tersier diperoleh dari kamus dan ensiklopedia.

\section{Teknik pengumpulan data}

Pengumpulan data penelitian dilakukan dengan cara studi dokumen-dokumen kepustakaan, khususnya aturan-aturan yang mengatur tentang hukum ekonomi syariah dan hukum perdata Indonesia. Peneliti semula melakukan pengumpulan data kepustakaan, memilah mana yang terkait dengan ganti rugi dan melakukan analisis deskriptif terhadap objek penelitian.

\section{Analisis data}

Analisis data menggunakan analisis kualitatif, yaitu menguraikan data yang diperoleh kemudian mengelompokkannya menurut kualitas dan kebenarannya menjawab permasalahan.

\section{Pembahasan}

\section{Hakikat Ganti Rugi Dalam Perspektif Hukum Ekonomi Syariah}

Ganti rugi (dhaman)bertujuan sebagai raf'u al-darar wa izalatuha, yaitu haruslah menghilangkan kerugian yang diderita oleh pihak yang dirugikan. Dhaman dalam Islam menyeimbangkan antara urusan dunia dan akhirat. Urusan dunia, ganti rugi berhubungan dengan psikis, kehormatan, dan harta benda. Urusan akhirat, ganti rugi itu merupakan utang yang harus dibayar, sehingga tidak menjadi tuntutan diakhirat kelak. 
Asmuni menyebutkan ganti rugi terhadap kerugian yang berhubungan dengan jiwa disebut jawabir al-dharar al-badaniyah mencakup kehilangan jiwa, kehilangan anggota badan atau fungsi keduanya. Jawabir model ini oleh para fuqaha' disebut dengan diyat (ganti rugi pembunuhan), ursy al-muqaddarah wa gairu almuqaddarah (denda luka yang sudah ditetapkan di dalam nas). Ganti rugi model ini sering disebut hukumatu 'adl, karena ukuran kualitas dan kuantitasnya diserahkan kepada otoritas peradilan yang adil.

Adapun ganti rugi yang berkaitan dengan harta (jawabir al-darar al-maliyah), seperti perampasan, perusakan terhadap barang atau manfaatnya mencakup dua hal, yaitu

1. Jawabir naqdiyah, yaitu ganti rugi dengan mengembalikan nilai jual barang (al-qimah).

2. Jawabir 'ainiyah, yaitu ganti rugi dengan mengembalikan barang itu sendiri atau menggantinya dengan barang yang sama dalam kasus-kasus perampasan dan penguasaan terhadap harta orang lain secara ilegal.

Al-Qur'an membolehkan dhaman sebagai suatu transaksi dalam bermuamalah terdapat dalam Q.S. Yusuf Ayat (72), artinya "Dan siapa yang dapat mengembalikannya akan memperoleh bahan makanan (seberat) beban unta dan Aku menjamin terhadapnya". ${ }^{9}$ Kemudian juga dapat dilihat dalam Q.S. AlBaqarah Ayat (194), Q.S. Syuro Ayat (40), Q.S. An-Nahl Ayat (126).Kemudian terdapat pula dalam hadis Rasulullah Saw "Pinjaman hendaklah dikembalikan dan orang yang menjamin hendaklah membayar" (H.R. Abu Daud dan Tirmidzi). Hadis lain juga menjelaskan bahwa sekelompok orang yang membawa jenazah seseorang kehadapan Rasulullah. Sebelum Rasulullah menyuruh mereka untuk menshalatkannya, karena dia punya utang, beliau bertanya siapa yang akan menanggung utangnya. Kemudian Abu Qatadah berkata "Utangnya saya yang menjamin". Lalu Rasulullah melakukan shalat atas mayat itu (H.R. Ahmad bin Hanbal, Imam Bukhari dan Nasai).

Para ulama membolehkan dhaman apabila rukun dan syaratnya terpenuhi. Adapun rukun dan syarat tersebut:

1. Pihak yang menjamin (dhamin) disyaratkan sudah baligh, berakal, merdeka, dan cakap bertindak hukum, sehingga dapat mengelola hartanya dan atas kehendak sendiri.

2. Orang yang berpiutang atau orang yang menerima jaminan (madhmunlah). Syaratnya ia harus diketahui dan dikenal oleh dhamin.

3. Orang yang berutang atau orang yang dijamin (madhmun anhu).

4. Objek jaminan utang (madhmun), berupa barang, uang atau orang. Disyaratkan bahwa objek ini harus diketahui dan telah ditetapkan keberadaannya. Apabila belum jelas dan tidak diketahui maka didalamnya terdapat unsur gharar.

5. Pernyataan yang dilafalkan oleh dhamin (sighah). Sighah disyaratkan harus dimaksudkan dan mengandung makna jaminan.

Dalam dhaman, orang yang berpiutang berhak menagih utang kepada orang yang berutang. Apabila utang dibayar oleh yang menjaminnya, orang yang menjamin tersebut dapat meminta ganti apa yang dibayarnya itu

${ }^{9} \mathrm{Al}-$ Quran, Terjemahan Kementrian Agama. 
kepada orang yang berutang apabila hal itu disebutkan ketika mengucapkan sighah dan orang yang berutang menyetujuinya.

Mengenai jaminan terhadap manusia, seseorang boleh menjamin orang lain selama jaminan itu menyangkut hak sesama manusia, tidak menyangkut hak Allah. Dasar kebolehan jaminan ini berdasar firman Allah dalam AlQur'an dalam surat Yusuf Ayat (66) artinya: "Aku sekali-kali tidak akan melepaskannya (pergi) bersama-sama kamu, sebelum kamu memberikan kepadaku janji yang teguh atas nama Allah, bahwa kamu pasti akan membawanya kepadaku kembali...". Termasuk dalam kategori ini menghadirkan seseorang kemuka pengadilan,seperti dalam tindak pidana qishash, qazf dan gasab. ${ }^{10}$

Akan tetapi, jika seseorang menjamin orang lain menyangkut hak Allah Swt, seperti dalam hukuman zina dan meminum minuman keras, jaminan tersebut tidak berlaku, karena yang bertanggung jawab hak Allah Swt adalah pihak yang melakukan perbuatan tersebut secara langsung.

Secara ringkas hal-hal yang dapat mengakibatkan dhaman ialah: ${ }^{11}$

1. Akad, seperti halnya jual beli, tsaman yang sudah ditentukan sebelum serah terima barang, pemesanan (salam), sewa-menyewa (ijarah), dan lain-lain. Artinya, dalam bermacam-macam akad ini jika kemudian terjadi hal-hal yang tidak diinginkan (rusak atau hilang) maka harus ada pihak yang ber- tanggungjawab untuk memberikan kompensasi.

2. Kekuasaan, yang dalam bahasa fiqh dikenal dengan istilah yad, yang dibagi menjadi dua: Pertama, penguasaan yang tidak atas dasar kepercayaan (yad ghayru amanah), yaitu penguasaan barang yang berada pada tangan seorang ghashib, orang yang sedang menawar, orang yang meminjam, dan orang yang melakukan jual beli yang tidak memenuhi syarat dan rukunnya (fasid). Demikian juga menurut salah satu pendapat seorang yang menjadi suruhan orang lain (ajir). Kedua, penguasaan yang didasarkan kepercayaan (yad mu'tamanah), seperti kewenangan yang terdapat dalam akad titipan (wadiah), kongsi (syirkah), persekutuan modal (mudharabah), perwakilan dan sebagainya. Kekuasaan atas dasar amanah ini apabila tidak digunakan sebagaimana mestinya akan berubah menjadi yad dhaman. Artinya, ketika barang yang dipercayakan kepadanya rusak maka ia wajib untuk menggantinya.

Asmuni berpendapat dalam menentukan ganti rugi, setidaknya harus didasarkan pada empat prinsip, ${ }^{12}$ yaitu Pertama, prinsip al-yusr (memudahkan) dalam menghitung dan mengukur ganti rugi tersebut untuk menghindari proses dan prosedur yang panjang di pengadilan agar para pencari keadilan tidak hlm. 520.

${ }^{10} \mathrm{Abdul}$ Azis Dahlan dkk (ed.), Ensiklopedi Hukum Islam, (Jakarta: PT Ichtiar Baru Van Hoeve), 2001,

${ }^{11}$ Abu Abdillah Badruddin Muhammad bin Bahadur al-Zarkasyi, al-Mantsur fi al-Qawaid Fiqh Syafi'l, (Beirut: Dar al-Kutub al-Ilmiyyah, 2000), hlm. Il/72. Lihat juga Taqiyuddin al-Hishni, Kitab al-Qawaid, (Riyadl: alRusyd, 1997), hlm. III/420-424. Lihat juga Abdul Haq dkk, Formulasi Nalar Fiqh, Telaah Kaidah Fiqh Konseptual, (Surabaya: Khalista, 2006), hlm. 127-128.

${ }^{12}$ Asmuni, Teori Ganti...Op.Cit., hlm. 110-111. 
terlalu lama menunggu haknya. Kedua, konsisten, yaitu terdapat keseragaman kualitas dan kuantitas ganti rugi dalam kasus yang sama pula. Ketiga, menyamakan (al-musawat) antara semua penduduk dalam menerima ganti rugi. Misalnya, jangan sampai ada pembedaan antara petani dengan pengusaha untuk ganti rugi kasus yang sama, karena prinsip dalam menetapkan darar bukan mempertimbangkan strata sosial atau kemampuan finansial. Keempat, harus terlebih dahulu mengidentifikasi dan menetapkan tingkat keterlibatan para pelaku. Karena hal ini akan menentukan kualitas ganti rugi yang akan dibebankan kepada mereka.

Menurut fiqh legal maxim dapat di analisis bahwa:

1. Kaidah la darar wa la dirar (tidak boleh ada bahaya dan tidak boleh membahayakan)

Kata darar memiliki arti melakukan suatu tindakan yang membahayakan dan merugikan orang lain secara mutlak. Konsep darar dalam sunah Rasulullah misalnya dijumpai dalam sebuah peristiwa bahwa pada saat itu Rasulullah berjalan-jalan ke pasar. Lalu, di sana la melihat seorang penjual buah dengan gerobaknya. la melihat buah-buahan di atas gerobak itu bagus-bagus, tetapi la heran ketika melihat air menitik dari gerobak itu. Rasulullah memasukkan tangannya ke dalam buah-buahan di atas gerobak tersebut. Ternyata buah-buahan yang bagus hanya ada di atas, sedangkan didalamnya banyak yang busuk. Ketika Rasulullah berkata "Siapa yang menipu kami bukanlah dari golongan kami" (HR. al-Bukhari dan Muslim dari Hurairah).

Hadis lain tentang sengketa antara seorang Anshar dan Samrah bin Jundab.
Samrah bertindak sewenang-wenang terhadap lahan pertanian orang Anshar tersebut, Rasulullah mengatakan "Kamu ini pembuat darar". (HR. al-Bukhari dan Muslim). Banyak hadis lainnya yang dijumpai bahwa berbuat darar itu di larang keras oleh Islam.

Darar sendiri ada tiga macam, yaitu darar yang berkaitan dengan kehartabendaan; darar yang berkaitan dengan fisik; dan darar yang berkaitan dengan kehormatan dan nama baik seseorang atau lembaga. Adapun yang terakhir ini disebut dengan darar adabi. Menjaga dan melindungi kehormatan dan nama baik masuk dalam kategori al-masalih al-daruriyah atau kemaslahatan primer.

Namun, dari aspek laindarar dibagi menjadi dua, yaituPertama,darar al-yasir (kerugian ringan). Para fuqaha pada umumnya berpendapat tidak ada dhaman terhadap darar ini. Menurut Asmuni, permasalahan ganti rugi terhadap darar yasir bersifat kondisional. Kedua, darar fakhisy (kerugian berat). Sementara kerusakan terhadap harta benda (dararmaliyah) dapat digolongkan menjadi kerusakan terhadap benda bergerak (manqulat), benda tidak bergerak ('iqarat), dan jasa (al-manafi'). ${ }^{13}$

Para fuqaha sepakat atas dhaman terhadap kerusakan benda bergerak (karena merampas barang, merusak atau menguranginya, mengubah bentuk barang atau mengeksploitasi pemanfaatannya). Sehubungan dengan dhaman barang-barang bergerak terdapat dua syarat:

Pertama,maliyatu al-manqul (barang bergerak itu betul-betul harta secara syara'). Almanqulat (bentuk jamak dari al-manqul) yang kehartaannya tidak diakui oleh syara' tidak dapat dilakukan ganti rugi terhadapnya. Itulah

${ }^{13}$ Ibrahim Fadil al-Dabbo, Dhaman al-Manafi' dirasah muqaranah fi al-fiqh al-islami wa al-qanun al-madani, (Amman, Beirut: Dar al-Bayariq, Dar 'Ammar, Cet. I, 1417 H/1997). 
sebabnya tidak ada dhaman dengan merusak bangkai, kulit bangkai, darah dan lain-lain yang pemanfaatannya dilarang oleh syara'. Hal yang juga tidak dapat dilakukan dhaman terhadapnya, yaitual-mubahat al-'âmmah (hak-hak umum),alkala' (rumput), al-ma' (air) dan al-nâr (api). Itulah sebabnya jika ada seseorang menimba sumur orang lain sampai kering, tidak dikenakan dhaman. Sebab pemilik sumur, bukan berarti memiliki air, berbeda kalau merampas air dari wadah yang lain. Hukum al-kala' (kecuali kalau dipelihara dan ditanam) dan al-nâr sama dengan hukum al-mâ'.

Kedua, tuqawwimu al-manqul (barang tersebut mengandung nilai ekonomis). alTaqawwum menurut Ibn Nujaim dapat ditetapkan berdasarkan dua hal, yaitu adanya unsur kehartaan (al-maliyah) dalam suatu barang dan barang tersebut boleh dimanfaatkan menurut syara'.

Adapun barang-barang tetap (al-'iqârât, immovable property), para fuqaha bersepakat wajibnya dhaman terhadapnya apabila merusak keseluruhan, sebagian atau merugikan pemiliknya. Berbeda dengan manâfi' terdapat perbedaan pendapat yang berkaitan dengan dhaman terhadapnya. Perbedaan ini sebagai konsekuensi dari silang pendapat yang terjadi antara fuqaha tentang status kehartaan almanafi' (maliyatu al-manafi'). Fuqaha' Hanafiyah terutama generasi awal tidak menetapkan dhaman terhadap al-manafi', karena wujudnya yang abstrak, sehingga ia tidak termasuk harta. Pendapat ini berbeda dengan pendapat mayoritas fuqaha dari berbagai mazhab, termasuk Syiah Imamiyah, menurut mereka dhaman terhadap al-manafi' sesuatu yang wajib.

Argumentasi fuqaha Ahnaf antara lain bahwa al-manafi' tidak mengandung nilai ekonomis. Statusnya sama dengan khamar dan bangkai. Artinya, al-itlâf tidak tergambar pada almanâfi' mengingat sifatnya yang abstrak. Pendapat ini oleh fuqaha Hanafiyah generasi mutaakhkhirin dianggap lemah, sehingga mereka mengevaluasi pendapat tersebut dan mengemukakan bahwa al-manâfi' adalah bagian dari al-mal (harta).

Adapun darar badaniyah meliputi jiwa, anggota badan atau hilangnya fungsi salah satu anggota badan. Misalnya, hilangnya pendengaran dan penglihatan. Terhadap semua kasus yang berkaitan dengan kerugian fisik seluruh atau sebagiannya, menurut para fuqaha berlaku hukum dhaman terhadapnya.

2. Kaidah al kharraju bidhamãn (hasil/manfaat itu diimbangi dengan tanggungan)

Dalam berbagai transaksi seringkali terjadi cacat pada barang yang terkadang mengandung unsur gharar didalamnya dan itu pun terkadang diketahui setelah transaksi dilakukan. Kejadian ini selalu diikuti dengan komplain yang dilakukan oleh konsumen dan mengembalikan barang tersebut, walaupun barang tersebut sudah pernah digunakan atau dimanfaatkannya. Tak jarang juga si penjual untuk menerima alasan si pembeli dengan dalih "barang yang sudah dibeli tidak dapat dikembalikan lagi".

Dari uraian tersebut kemudian kaidah ini memiliki taji dalam penyelesaiannya. Substansi kaidah al Kharraju Bidhamãn ${ }^{14}$ ialah pemanfaatan barang yang telah dilakukan pembeli sehingga akan menjadi sebuah bentuk imbangan atas kewajiban mengganti barang yang telah dijual kepadanya, ketika terjadi kerusakan atau hilang, selama barang yang tersebut masih berada ditangannya selama

${ }^{14}$ A. Djazuli, Kaidah-Kaidah Fikih, (Jakarta: Kencana, 2006), hlm. 133. 
masa khiyar (masa tunggu untuk menentukan apakah jual beli akan tetap berlangsung atau dibatalkan).

Kaidah ini tersusun dari dua kata, yaitu al-kharraj dan al-dhaman. Kata al-kharraj dalam kamus berarti hasil bumi atau jasa pekerjaan yang dilakukan seorang budak. Al-kharraj diartikan segala sesuatu yang dihasilkan atau dikeluarkan benda, karena itu dapat dikatakan bahwa al-kharraj pohon ialah buahnya dan alkharraj hewan adalah susu serta anakanaknya. ${ }^{15}$

Dhaman diartikan sebagai tanggungan atau kesanggupan. Al-Zarkasyi berpendapat dhaman ialah segala sesuatu yang telah dihasilkan barang yang telah ditransaksikan baik yang dihasilkan nantinya akan menjadi milik pembeli sebagai imbangan ganti rugi yang harus ditanggung pada suatu barang yang dibeli, bila terjadi kerusakan atau cacat pada saat masa khiyar. Karena pada dasarnya ia wajib mendapatkan ganti rugi, ketika barang yang sudah dibelinya rusak, namun ganti rugi ini sudah tercukupkan dengan pemanfaatan barang yang telah dibelinya.

Secara umum kaidah ini menjangkau segala permasalahan dengan latar belakang peristiwa yang sama. Setiap permasalahan yang didalamnya terdapat pihak yang mengalami kerugian yang berhak mendapatkan balasan yang setimpal dengan kerugiannya, akan masuk dalam kaidah ini. Sudah sewajarnya apabila mengalami kerugian setiap orang pasti menghendaki untuk mendapatkan ganti rugi yang berimbang. Dengan pertimbangan bahwa pihak yang telah diuntungkan harus bersedia untuk menolong orang yang merasa dirugikan oleh dirinya.
Namun, kaidah al Kharraju Bidhamãn janganlah dibaca secara literal, karena akan menimbulkan dua makna yang berdampak tidak baik. Pertama, apabila kharraj dikatakan sebagai imbangan dari dhaman, tentu memiliki pemahaman bahwa apabila terdapat barang yang dapat "berkembang" atau bertambah sebelum barang diserah terimakan, tentu pertambahan itu tetap menjadi milik si penjual, baik akadnya sudah sempurna ataupun masih ada peluang untuk merusak akad. Berangkat dari itu, kemudian pertambahan tentunya akan menjadi milik si penjual dan berkonsekuensi terhadap terwujudnya ganti rugi (dhaman) yang harus ditanggung pembeli bila terjadi kerusakan.Kedua, andaikan yang menjadikan kharraj menjadi milik penjual karena alasan dhaman, tentunya pertambahan (zawa'id) akan menjadi milik orang yang meng-ghasab suatu barang. Karena orang yang meng-ghasab lebih tertuntut membayar dhaman daripada tuntutan dhaman yang harus dilakukan selain orang yang meng-ghasab. Alasan inilah yang menjadikan Imam Hanifah mengatakan bahwa seorang peng-ghasab tidak akan dibebani untuk memberikan ganti rugi atas pemanfaatan pertambahan barang yang di-ghasab.

Dari hal di atas, kaidah ini harus dipahami bahwa ganti rugi (dhaman) yang dimaksud ialah ganti rugi atas kepemilikan suatu barang (dhaman al-milk), sehingga ketika ada orang yang meng-ghasab sebuah barang dan barangnya berada di tangan seseorang, ia tidak berhak untuk mendapatkan kemanfaatan dari barang yang di-ghasab. Di samping ia tetap harus dibebani ganti rugi jika terjadi kerusakan barang, kewajiban mengganti ini dikarenakan dalam pandangan syar'i status dari barang yang

\footnotetext{
${ }^{15} \mathrm{Ahmad}$ bin Muhammad al-Hamawi, Ghamzu 'Uyun al-Bashair, (Beirut: Dar al-Kutub al-Ilmiyah, Volume 1, Tanpa Tahun), hlm. 431.
} 
di-ghasab walaupun berada ditangannya, jelas bukan miliknya.

Adapun yang dimaksud cacat dalam kaidah ini diantaranya hal-hal yang timbul dari barang yang dijual, baik berupa benda atau manfaatyang akan menjadi milik pembeli secara mutlak. Artinya, baik barang yang dibeli (ketika mengalami kerusakan) harus dikembalikannya setelah pembeli menerimanya atau sebelumnya.

\section{Hakikat Ganti Rugi Dalam Perspektif Hukum Perdata Indonesia}

Sebelum menjelaskan ganti rugi berdasarkan perspektif hukum perdata Indonesia, sejenak dideskriptifkan tentang konsep ganti rugi dari hukum Romawi. Hal ini penting, karena akar konsep hukum perdata dari Belanda berasal dari hukum Romawi. Hukum Romawi mengatur tentang cara menuntut ganti rugi terhadap kontrak jika salah satu pihak cidera janji dari kontrak yang telah dibuatnya. Saat itu hukum Romawi membenarkan penyanderaan terhadap pihak yang menimbulkan kerugian, kemudian akan dibebaskan ketika pihak tersebut telah membayar kerugian yang ditimbulkannya.

Secara logika, cara yang dilakukan oleh hukum Romawi tidak masuk akal karena bagaimana pihak yang menimbulkan kerugian untuk membayar kerugian yang dibuatnya, jika ia disandera. Sehingga efek yang timbul ialah kerugian tersebut dibayar oleh keluarganya. Cara ini tidaklah begitu efektif dalam konsep ganti rugi, sehingga kemudian berkembang cara ganti rugi finansial dalam jumlah yang besar. Selain itu, dalam hukum Romawi juga menerapkan paksaan dalam menjalankan kontrak (specific performance) bagi pihak yang menimbulkan kerugian atau disebut dengan istilah Actio Arbitraria. ${ }^{16}$

Sebagai perbandingan, melihat perkembangan ganti rugi di Amerika mulai gencar pada paruh kedua abad ke-19. Berbagai model perhitungan ganti rugi mulai diperkenalkan meskipun model ganti rugi yang disebut dengan lost opportunities belum bisa diterima saat itu. Begitu juga di Inggris, dalam kasus Hadley vs Baxendale (1854), ganti rugi dalam bentuk lost oportunities belum mendapat tempat. ${ }^{17}$ Ganti rugi yang familiar digunakan ialah ganti kerugian berupa natural consequences (konsekuensi alamiah). Prinsip-prinsip ganti rugi karena kontrak pada zaman dan prinsip itu masih berlaku hingga sekarang, sebagai berikut:

1. Bersifat rasional;

2. Dapat dikalkulasikan;

3. Terbatas akibat yang natural dari ganti rugi; dan

4. Keterdugaan akan kerugian.

Abdulkadir Muhammad mengatakan di Indonesia persoalan terkait ganti rugi membahas tentang apa yang dimaksud dengan ganti rugi itu, kapan ganti rugi itu timbul, apa ukurannya ganti rugi itu serta bagaimana pengaturannya. ${ }^{18}$ Menurut Pasal 1243 Kitab Undang-Undang Hukum Perdata (KUH Perdata), pengertian ganti rugi lebih menitikberatkan pada ganti kerugian karena tidak terpenuhinya suatu perikatan, yakni kewajiban debitur untuk mengganti kerugian kreditur akibat kelalaian pihak debitur melakukan wanprestasi. Sehingga penekanan ganti rugi itu ialah ganti rugi yang timbul karena debitur

\footnotetext{
${ }^{16}$ Munir Fuadi, Perbandingan Hukum Perdata, (Bandung: PT Citra Aditya Bakti, 2005), hlm. 67.

${ }^{17}$ Ibid, hlm. 71.

${ }^{18}$ Abdulkadir Muhammad, Hukum Perikatan, (Bandung: PT Citra Aditya Bakti, 1992), hlm. 39.
} 
melakukan wanprestasi karena lalai. Ganti rugi tersebut meliputi:

1. Ongkos atau biaya yang telah dikeluarkan (cost), misalnya biaya materai, biaya iklan dan lain-lain.

2. Kerugian yang sesungguhnya karena kerusakan, kehilangan benda milik kreditur akibat kelalaian debitur. Kerugian yang sungguh-sungguh diderita, misalnya akibat keterlambatan penyerahan mengakibatkan buah menjadi busuk dan lain-lain.

3. Bunga atau keuntungan yang diharapkan (interest), karena debitur lalai maka mengakibatkan kreditur kehilangan keuntungan yang diharapkannya.

Menurut ketentuan Pasal 1243 KUH Perdata, ganti kerugian karena tidak dipenuhinya suatu perikatan, barulah mulai diwajibkan apabilah debitur setelah dinyatakan Ialai memenuhi perikatannya, tetap melalaikannya atau sesuatu yang harus diberikan atau dibuat dalam tenggang waktu yang telah dilampaukannya.

Adapun yang dimaksud kerugian dalam pasal ini ialah kerugian yang timbul karena debitur melakukan wanprestasi (lalai memenuhi perikatan). Kerugian tersebut wajib diganti oleh debitur terhitung sejak ia dinyatakan lalai. Menurut Yahya Harahap, kewajiban ganti rugi tidak dengan sendirinya timbul pada saat kelalaian. Ganti rugi baru efektif, setelah debitur dinyatakan Ialai atau disebut dengan "in gebrekke stelling" atau "in morastelling".

Menurut Abdul Kadir Muhammad, dalam ganti kerugian itu tidak selalu ketiga unsur yang terdapat dalam Pasal 1243 tersebut harus ada, mungkin kerugian yang sesungguhnya atau mungkin hanya ongkos-ongkos atau biaya atau mungkin kerugian sesungguhnya ditambah dengan ongkos atau biaya. Ganti kerugian itu harus dihitung berdasarkan nilai uang, jadi harus berupa uang bukan berupa barang. ${ }^{19}$ Dalam ganti kerugian itu tidak senantiasa ketiga unsur tersebut ada. Minimal ganti kerugian itu adalah kerugian yang real diderita oleh kreditur.

Untuk menghindari tuntutan sewenangwenang pihak kreditur, undang-undang memberikan batasan-batasan ganti kerugian yang harus diganti oleh debitur sebagai akibat dari kelalaiannya (wanprestasi) yang termaktub dalam Pasal 1247 dan 1248 KUH Perdata.

Pasal 1247 KUH Perdata:

"Debitur hanya diwajibkan membayar ganti kerugian yang nyata telah atau sedianya harus dapat diduga sewaktu perikatan dilahirkan, kecuali jika hal tidak dipenuhinya perikatan itu disebabkan oleh tipu daya yang dilakukan olehnya".

Pasal 1248 KUH Perdata:

"Jika tidak dipenuhinya perikatan itu disebabkan oleh tipu daya debitur, pembayaran ganti rugi sekedar mengenai kerugian yang diderita oleh kreditur dan keuntungan yang hilang baginya, hanyalah terdiri atas apa yang merupakan akibat langsung dari tidak dipenuhinya perikatan". Kedua pasal tersebut menampilkan ada 2 (dua) pembatasan kerugian, yaitu Pertama, kerugian yang dapat diduga ketika membuat perikatan.Kedua, kerugian sebagai akibat langsung dari wansprestasi. Kedua macam kerugian inilah yang menjadi kewajiban ganti rugi oleh debitur kepada kreditur (pihak yang dirugikan).

Abdulkadir Muhammad menyebutkan persyaratan "dapat diduga" dalam Pasal 1247 KUH Perdata tidak hanya ditujukan kepada

19Wirjono Prodjodikoro, Azas-Azas Hukum Perjanjian, (Bandung: Mandar Maju, 2000), hlm. 177. 
kemungkinan timbulnya kerugian saja, melainkan juga meliputi besarnya jumlah kerugian. Jika jumlah kerugian itu melampaui batas yang dapat diduga maka kelebihan yang melampaui batas itu tidak boleh dibebankan kepada debitur, kecuali jika debitur ternyata telah melakukan tipu daya.

Persyaratan "akibat langsung" mengarahkan kepada teori kausalitas. Terdapat 2 (dua) macam teori kausalitas, yaitu (a) teori conditio sine qua non (Von Buri), (b) teori adequate (von Kries). Teori conditio sine qua non mensyaratkan setiap peristiwa adalah penting dan menyebabkan terjadinya akibat. Teori ini terlalu luas, sehingga sulit untuk dipakai menentukan terjadinya akibat.

Teori adequate lebih terbatas lagi, menurut teori ini yang dimaksud akibat langsung ialah akibat yang menurut pengalaman manusia yang normal dapat diharapkan atau dapat diduga akan terjadi. Dalam hubungan ini, debitur berdasarkan pengalaman yang normal dapat menduga bahwa adanya wanprestasi itu akan timbul kerugian bagi kreditur. Menurut Vollmar, dalam praktik peradilan teori adequate yang sering diikuti. $^{20}$

Selain pembatasan yang terdapat dalam Pasal 1247 dan 1248 KUH Perdata, terdapat juga dalam Pasal $1250 \mathrm{KUH}$ Perdata yang berbunyi:"Dalam tiap-tiap perikatan yang semata-mata berhubungan dengan pembayaran sejumlah uang, pembayaran ganti kerugian sekedar disebabkan oleh terlambatnya pelaksanaan, hanya terdiri dari bunga yang ditentukan oleh undang-undang".

Bunga dalam hal ini ialah bunga karena lalai atau terlambat membayar sejumlah uang itu. Bunga yang harus dibayar karena lalai ini disebut moratoir interest, sebagai hukuman bagi debitur. Moratoir berasal dari bahasa latin dari kata morayang artinya lalai.

Ganti rugi yang berupa moratoir interest ini harus dibayar oleh debitur kepada kreditur tanpa kewajiban pembuktian lagi oleh kreditur. Besar bunganya ialah $6 \%$ setahun, tanpa mengurangi ketentuan lainnya dengan undangundang yang menetapkan bunga yang lebih tinggi (Stb. 1848-22 jo. Stb. 1849-63).

Moratoir interest harus dibayar terhitung sejak hari dituntutnya ke muka pengadilan, jadi sejak dimasukkan surat gugatan ke Pengadilan Negeri. Berdasarkan pengecualian jika dalam perjanjian telah ditentukan cara perhitungan atau besarnya bunga itu maka yang diperlakukan ialah apa yang telah diperjanjikan (Pasal 1250 Ayat (2) dan (3) KUH Perdata). Pengecualian Pasal 1250 Ayat (3) ini antara lain dalam Pasal 1401, 1515, 1626 Ayat (3). Menurut yurisprudensi, Pasal $1250 \mathrm{KUH}$ Perdata ini tidak dapat diperlakukan terhadap perikatan yang timbul karena perbuatan melawan hukum.

Uraian lebih lanjut tentang ganti rugi akan penulis himpun berdasarkan beberapa pendapat pakar hukum perdata, yaitu

1. Prof. Purwahid Patrik ${ }^{21}$

Apabila undang-undang berbicara tentang penggantian kerugian yang timbul karena tidak memenuhi perikatan maka yang dinyatakan kerugian adalah kerugian yang nyata yang timbul dari wanprestasi. Penggantian kerugian untuk kerugian yang disebabkan oleh wanprestasi menurut pendapat umum hanya dapat diganti dengan uang karena uang adalah bentuk pengganti kerugian yang paling sedikit menimbulkan perselisihan.

${ }^{20}$ H.F.A. Vollmar, Pengantar Studi Hukum Perdata Jilid II, (Jakarta: Rajawali, 1974), hlm. 69.

${ }^{21}$ Purwahid Patrik, Dasar-Dasar Hukum Perikatan, (Bandung: Mandar Maju, 1994), hlm. 14-17. 
Kerugian dibagi menjadi 2 (dua), yaitu kerugian yang nyata diderita (damnum emergens) meliputi biaya dan rugi dan keuntungan yang tidak diperoleh (Iucrum cessans) meliputi bunga.

Jumlah dari penggantian kerugian (a) pihak-pihak dapat menentukan sendiri jumlah penggantian kerugian, (b) undang-undang juga dapat menentukan dengan tegas, atau (c) jika pihak-pihak tidak menentukan jumlah pengganti kerugian dan undang-undang tidak menentukan secara tegas maka jumlah pengganti kerugian ditentukan sedemikian besarnya sehingga kekayaan dari kreditur harus sama, seperti kalau debitur telah memenuhi kewajibannya.

Perlu diketahui bahwa undang-undang hanya mengatur penggantian kerugian yang bersifat material. Kemungkinan terjadi bahwa kerugian itu menimbulkan kerugian immaterial, tidak berwujud, moril, idiil, tidak dapat dinilai dengan uang, tidak ekonomis, yaitu berupa sakitnya badan, penderitaan batin, rasa takut, dan sebagainya. Umumnya terhadap kerugian yang immaterial ini dapat digugat dengan dalih perbuatan melawan hukum.

\section{J. Satrio 22}

Dalam bukunya J. Satrio lebih banyak mengulas tentang ganti rugi pada perbuatan melawan hukum. Undang-undang dalam Pasal 1370, 1371 dan 1372 KUH Perdata memberikan pengaturan yang menyimpang dari ketentuan Pasal 1365, yang dalam hal ada perbuatan melanggar hukum yang menimbulkan kematian, luka atau cacat badan menetapkan bahwa "besarnya ganti kerugian harus dihitung dengan memperhitungkan kedudukan dan kemampuan kedua belah pihak dan keadaan".
Penyimpangan tersebut meliputi 2 (dua) pembatasan yang dikenal dalam Pasal 1365 , yaitu besarnya kerugian dan orang-orang yang berhak atas ganti rugi.

Besarnya ganti rugi dalam Pasal 1370 dan 1372 yang mengatakan bahwa besarnya ganti rugi harus dinilai "menurut kedudukan dan kekayaan kedua belah pihak serta menurut keadaan" menunjukkan kepada kita bahwa di sini ada pembatasan mengenai besarnya ganti rugi yang bisa dituntut dari orang yang harus bertanggung jawab. Dengan demikian, ketentuan tersebut berbeda dari ketentuan Pasal 1365 yang mengatakan bahwa "orang yang melakukan tindakan melawan hukum dan karena salahnya menimbulkan kerugian pada orang lain harus mengganti kerugian tersebut". Kerugian dalam pasal ini ditafsirkan kerugian yang diderita.

Melirik Pasal 1371, kerugian yang diatur merupakan kerugian dalam wujud kematian, luka atau cacat badan yang semuanya merupakan kerugian idiil atau moril belaka dan karena memang tak dapat dinilai dengan uang. Terkait ganti rugi yang menimbulkan kematian, pengadilan Indonesia mempunyai istilah tersendiri, yaitu uang duka yang dimaksudkan tuntutan ganti rugi tersebut sebagai pernyataan duka yang bisa diwujudkan dalam sejumlah uang dan sekedar dapat meringankan penderitaan korban lahir maupun batin. Karena sebutannya uang duka maka jumlah ganti ruginya pun relatif dan wajar sekali apabila disesuaikan dengan kedudukan dan kemampuan serta keadaan pada saat peristiwa terjadi. Sehingga dapat disimpulkan bahwa pada prinsipnya ganti rugi tidak selalu benar-benar harus sebesar kerugian yang diderita.

22J. Satrio, Hukum Perikatan (Perikatan yang Lahir dari Undang-Undang), (Bandung: PT Citra Aditya Bakti, 1994), hlm. 128-133. 
Terkait ganti rugi ada asas yang melekat didalamnya, yaitu (a) bahwa yang dinamakan ganti rugi pada prinsipnya mengganti seluruh kerugian dan hanya pada kerugian-kerugian tertentu saja prinsip itu disimpangi, yaitu tentang kerugian yang bersifat idiil, (b) kerugian itu juga harus merupakan kerugian yang benar-benar diderita. Perkecualiannya ada, yaitu pada masalah turunnya nilai benda yang telah diperbaiki.

\section{R. Soetojo Prawirohamidjojo ${ }^{23}$}

Sumber dari pada kewajiban ganti rugi (vergoedingsplicht) dapat melalui wanprestasi atau onrechtmatigedaad. Pasal 1246 sampai 1252 KUH Perdata memberikan pedoman di dalam memperhitungkan besarnya ganti rugi dan kewajiban pemberian ganti rugi itu. Menurut H.R. pasal-pasal tersebut hanya berlaku untuk ganti rugi yang bersumber pada wanprestasi (H.R. 28 Desember 1906, W. 8477; H.R. 23 Juni 1922 W. 10948). Tetapi, mengenai ganti rugi yang bersumber pada onrechtmatigedaad pasal-pasal tersebut hanya berlaku secara indirect.

Ganti rugi yang bersumber dari wanprestasi, pertama-tama harus dilakukan dengan suatu jumlah uang (geldsom). Hal ini didasari dalam pasal-Pasal 607 dan $608 \mathrm{Rv}$, dimana secara berturut-turut dikatakan dengan istilah beloop dan som yang hanya menunjukkan akan suatu jumlah uang.

4. Prof. Dr. Mariam Darus Badrulzaman, $\mathrm{dkk}^{24}$

a. Kewajiban ganti rugi dalam perikatan untuk memberikan sesuatu

Mengenai perikatan untuk memberikan sesuatu, undang-undang tidak merumuskan gambaran yang sempurna. Dari ketentuan Pasal 1235 KUH Perdata dapat disimpulkan bahwa perikatan untuk memberikan sesuatu adalah perikatan untuk menyerahkan dan merawat benda, sampai pada saat penyerahan dilakukan.

Kewajiban menyerahkan merupakan kewajiban pokok dan kewajiban merawat merupakan kewajiban preparatoir. Kewajiban preparatoir maksudnya ialah hal-hal yang harus dilakukan oleh debitur menjelang penyerahan dari benda yang diperjanjikan. Dengan perawatan itu, diharapkan benda tersebut utuh, berada dalam keadaan baik dan tidak turun harga.

Kewajiban ganti rugi dalam perikatan untuk memberikan sesuatu diatur dalam Pasal 1236 KUH Perdata yang menyebutkan si debitur berwajib memberikan ganti biaya, rugi dan bunga kepada si kreditur apabila ia telah membawa dirinya dalam keadaan tidak mampu untuk menyerahkan kebendaannya atau tidak merawat sepatutnya guna menyelamatkannya. Dalam Pasal 123 KUH Perdata menyebutkan "dalam hal adanya perikatan untuk memberikan suatu kebendaan tertentu, kebendaan itu semenjak perikatan dilahirkan adalah atas tanggungan si berpiutang (kreditur). Jika si berutang lalai akan menyerahkannya maka semenjak saat kelalaian, kebendaan adalah atas tanggungannya".

Dalam hal debitur lalai menyerahkan benda maka semenjak saat kelalaian menjadi tanggungan debitur. Dengan demikian, maka hukuman untuk membayar ganti rugi, biaya dan bunga, dibebankan pada debitur yang tidak mampu menyerahkan benda ataupun merawatnya karena kesalahannya.

${ }^{23}$ R. Soetojo Prawirohamidjojo, Hukum Perikatan, (Surabaya: PT Bina IImu, 1979), hlm. 43-47.

${ }^{24}$ Mariam Darus Badrulzaman, Kompilasi Hukum Perikatan, (Bandung: PT Citra Aditya Bakti, 2001), hlm. 11-33. 
b. Kewajiban ganti rugi dalam perikatan untuk berbuat sesuatu dan tidak berbuat sesuatu

Kewajiban ganti kerugian dalam perikatan untuk berbuat sesuatu dan tidak berbuat sesuatu diatur dalam Pasal 1239 dan $1240 \mathrm{KUH}$ Perdata. Pasal 1239 berbunyi tiap-tiap perikatan untuk berbuat sesuatu atau untuk tidak berbuat sesuatu, apabila siberutang tidak memenuhi kewajibannya, mendapatkan penyelesaiannya dalam kewajiban, memberikan penggantian biaya, rugi dan bunga. Pasal 1240 berisi dalam pada itu si berpiutang adalah berhak menuntut akan penghapusan segala sesuatu yang telah dibuat berlawanan dengan perikatan dan bolehlah ia minta supaya dikuasakan oleh hakim untuk menyuruh menghapuskan segala sesuatu yang telah dibuat tadi atas biaya si berutang, dengan tidak mengurangi hak menuntut penggantian biaya, rugi dan bunga jika ada alasan untuk itu.

c. Kewajiban ganti rugi dalam perikatan untuk tidak berbuat sesuatu

Terkait hal ini, pengaturannya diatur dalam Pasal 1242 KUH Perdata yang mengatakan jika perikatan itu bertujuan untuk tidak berbuat sesuatu maka pihak yang manapun jika yang berbuat berlawanan dengan perikatan, karena pelanggaran itu dan karena itupun saja, berwajiblah ia akan penggantian biaya, rugi dan bunga. Pasal 1243 mengatakan penggantian biaya, rugi dan bunga karena tidak dipenuhinya suatu perikatan, barulah mulai diwajibkan apabila yang berutang setelah dinyatakan lalai memenuhi perikatannya, tetap melalaikannya atau jika sesuatu yang harus diberikan atau dibuatnya hanya dapat diberikan atau dibuat dalam tenggang waktu yang telah dilampaukannya.

Dalam suatu perikatan apabila debitur karena kesalahannya tidak melaksanakan apa yang diperjanjikan maka dikatakan bahwa debitur itu ingkar janji. Ada juga terjadi kemungkinan bahwa debitur itu tidak melaksanakan apa yang diperjanjikan itu bukan karena kesalahan debitur. Dalam hal ini, dikatakan bahwa debitur berada dalam keadaan memaksa dan masalah siapa yang wajib memikul kerugian diselesaikan oleh teori risiko.

\section{Penutup}

Indonesia menganut dual system dalam hal penerapan hukum ekonomi, yaitu hukum konvensional atau hukum perdata Indonesia dan hukum ekonomi syariah. Implikasi dari dual system tersebut berpengaruh pada seluruh aspek ekonomi termasuk dalam konsep ganti rugi. Ada beberapa hal perbedaan yang fundamental dari konsep ganti rugi menurut hukum perdata Indonesia dengan hukum ekonomi syariah. Konsep ganti rugi hukum perdata Indonesia mengacu kepada $\mathrm{KUH}$ Perdata, yang menekankan setiap penggantian kerugian baik itu material maupun immaterial selalu dijumlahkan dengan sejumlah uang. Konsep ganti rugi dalam hukum ekonomi syariah tidak menyebutkan dengan apa mesti diganti, boleh saja dengan uang atau bisa saja dengan jasa atau bahkan dianjurkan untuk memberi maaf kepada pihak yang merugikan tersebut, sehingga pilihan-pilihan dalam konsep hukum ekonomi syariah lebih akomodatif dan disesuaikan dengan keadaannya. Selain itu, dalam konsep ganti rugi perspektif hukum perdata Indonesia mengakomadir unsur bunga dalam pembayaran ganti kerugian. Dalam perspektif hukum ekonomi syariah unsur bunga sangatlah diharamkan karena bertentangan dengan Al-Quran dan Sunah.

\section{Referensi}

Abu Abdillah Badruddin Muhammad bin Bahadur al-Zarkasyi. 2000. al-Mantsur fi al-Qawaid 
Fiqh Syafi'l. Beirut: Dar al-Kutub alIImiyyah.

A. Djazuli. 2006. Kaidah-Kaidah Fikih. Jakarta: Kencana.

Abdul Azis Dahlan dkk (ed.). 2001. Ensiklopedi Hukum Islam. Jakarta: PT Ichtiar Baru Van Hoeve.

Abdul Haq dkk. 2006. Formulasi Nalar Fiqh, Telaah Kaidah Fiqh Konseptual. Surabaya: Khalista.

Abdulkadir Muhammad. 1992. Hukum Perikatan. Bandung: PT Citra Aditya Bakti.

Ahmad bin Muhammad al-Hamawi. tanpa tahun. Ghamzu 'Uyun al-Bashair, Beirut: Dar alKutub al-IImiyah.

Asmuni.Teori Ganti Rugi (Dhaman) Perspektif Hukum Islam.Jurnal Millah. Volume VI. Nomor 2. Februari 2007.

Elizabeth A. Martin. tanpa tahun. A Dictionary of Law. New York: Oxford University Press.

Habib Nazir dan Muhammad Hasanuddin. 2008.Ensiklopedi Ekonomi dan Perbankan Syariah. Bandung: Kafa Publishing.

H.F.A. Vollmar. 1994. Pengantar Studi Hukum Perdata Jilid II. Jakarta: Rajawali.

Ibrahim Fadil al-Dabbo. 1997. Dhaman alManafi' dirasah muqaranah fi al-fiqh alislami wa al-qanun al-madani, Amman. Beirut: Dar al-Bayariq, Dar 'Ammar.

J. Satrio. 1994. Hukum Perikatan (Perikatan yang Lahir dari Undang-Undang), Bandung: PT Citra Aditya Bakti.
Kamus Bahasa Besar Bahasa Indonesia. 2008. Jakarta: Pusat Bahasa.

Kristin Olivia Sumaa. Ganti Rugi Menurut Pasal 95 dan Pasal 96 KUHAP Dalam Proses Pelaksanaannya Terhadap Error in Persona. JurnalLex Crimen. Volume I. Nomor 3. Juli-September 2012.

Kuspraningrum Emilda. Perbandingan Ganti Rugi pada Gugatan Wanprestasi dan Gugatan Perbuatan Melawan Hukum. Jurnal Risalah Hukum. Volume 3. Nomor 1. Juni 2007.

Mariam Darus Badrulzaman. 2001. Kompilasi Hukum Perikatan. Bandung: PT Citra Aditya Bakti.

Munir Fuadi. 2005. Perbandingan Hukum Perdata. Bandung: PT Citra Aditya Bakti.

Purwahid Patrik. 1994. Dasar-Dasar Hukum Perikatan. Bandung: Mandar Maju.

R. Soetojo Prawirohamidjojo. 1979. Hukum Perikatan. Surabaya: PT Bina IImu.

Taqiyuddin al-Hishni. 1997. Kitab al-Qawaid. Riyadl: al-Rusyd.

Wesman Endom dan Subarudi. Metode Pendekatan Penilaian Ganti Rugi Lahan Hutan.Jurnal Analisis Kebijakan Kehutanan. Volume 8. Nomor 1. April 2011. Wirjono Prodjodikoro. 2000. Azas-Azas Hukum Perjanjian. Bandung: Mandar Maju.

Yowanda P. Lumentut. Tanggung Jawab Pelaku Usaha Memberikan Ganti Rugi Atas Kerusakan Barang yang Merugikan Konsumen. JurnalLex Privatum. Volume I. Nomor 3. Juli 2013. 